Sains Malaysiana 51(1)(2022): 95-105

http://doi.org/10.17576/jsm-2022-5101-08

\title{
Engineering Lactococcus lactis as a Cell Factory for the Production of Limonene
}

(Kejuruteraan Lactococcus lactis sebagai Kilang Sel untuk Penghasilan Limonena)

\author{
Nurul ‘Aishah Shaili, Adelene Ai-Lian SonG*, Sarah Othman, Lionel Lian Aun In, Janna OnG- \\ ABDULLAH \& RAHA ABDUL RAHIM
}

\begin{abstract}
Limonene is a plant monoterpene which contributes significantly to the scent of most essential oils due to its pleasant fragrance. The compound had been reported to have anti-cancer properties against several types of cancer including colorectal cancer. However, the production of this compound in nature is limited because it is produced as a secondary metabolite. To overcome these challenges, Lactococcus lactis was developed as a heterologous host for the production of limonene. A synthesized limonene synthase (LS) from Mentha spicata (mint) was cloned into L. lactis NZ9000. Western blot analysis using mouse IgG His-Tag monoclonal antibody showed successful LS expression by L. lactis at the size of $\sim 55 \mathrm{kDa}$. GC-MS analysis results showed that limonene production was optimum after $24 \mathrm{~h}$ of induction ( 8.0 ppm). Metabolic engineering was attempted to enhance the limonene production by overexpression of lactococcal 3-hydroxy-3methylglutaryl coenzyme A reductase (HMGR) and mevalonate kinase (mvk) genes in the bacterial host. The recombinant L. lactis carrying pNZ:LSMM plasmid successfully enhanced the limonene production to two-fold ( 15.1 ppm) after $24 \mathrm{~h}$ of induction. The outcomes of this study show the potential of $\mathrm{L}$. lactis to produce plant proteins and bioactive compounds production, which prospectively leads to an oral delivery system for anti-cancer compounds.
\end{abstract}

Keywords: Isoprenoid; lactic acid bacteria; metabolic engineering; monoterpene

ABSTRAK

Limonena adalah monoterpena yang menyumbang secara signifikan kepada aroma bagi kebanyakan minyak pati kerana harumannya yang menyenangkan. Bahan ini dilaporkan mempunyai sifat anti-kanser terhadap beberapa jenis kanser termasuk kanser kolorektum. Walau bagaimanapun, penghasilan bahan ini adalah terhad kerana ia dihasilkan sebagai metabolit sekunder. Untuk mengatasi cabaran ini, Lactococcus lactis telah dibangunkan sebagai hos heterologus untuk penghasilan limonena. Gen limonena sintes (LS) yang disintesis daripada Mentha spicata (pudina) telah diklon ke dalam L. lactis NZ9000. Analisis pemblotan Western menggunakan antibodi monoklon IgG His-Tag tikus menunjukkan protein LS berjaya diekspreskan dan mempunyai berat molekul $\sim 55 \mathrm{kDa}$. Keputusan analisis GC-MS menunjukkan bahawa pengeluaran limonena adalah optimum selepas 24 jam induksi ( 8.0 ppm). Kejuruteraan metabolik dilakukan untuk meningkatkan penghasilan limonena dengan memasukkan gen 3-hidroksi-3-metilglutaril koenzim A reduktase (HMGR) dan mvk ke dalam hos bakteria. L. lactis rekombinan yang mengandungi plasmid pNZ:LSMM hanya berjaya meningkatkan pengeluaran limonena kepada dua kali ganda ( 15.1 ppm) selepas 24 jam induksi. Hasil kajian ini menunjukkan potensi L. lactis untuk penghasilan protein tumbuhan dan sebatian bioaktif, secara prospektif membawa kepada sistem penghantaran oral untuk sebatian anti-kanser.

Kata kunci: Bakteria asid laktik; isoprenoid; kejuruteraan metabolik; monoterpena

\section{INTRODUCTION}

Isoprenoids are organic compounds that are naturally produced by plants where they possess a wide range of functions such as pharmacological activities, flavour enhancers and fragrance additives. Isoprenoids are generated through two metabolic pathways, the mevalonate (MVA) or the non-mevalonate pathway, which is also known as the 2-C-methyl-D-erythritol-4-phosphate (MEP) pathway. All eukaryotes use the MVA pathway to produce isoprenoids, except for plants which possess both pathways which take place in different organelles (RodríguezConcepción \& Boronat 2002). The MVA pathway is localized in the cytoplasm to produce sesquiterpenes and steroids, while other monoterpenes, carotenoids and quinones are 
formed via the MEP pathway in the plastid (Crocoll et al. 2010). Most prokaryotes including Escherichia coli use the MEP pathway, however, Staphylococcus aureus and L. lactis which are Gram-positive bacteria, utilizes the MVA pathway for the production of isoprenoids through the evolution process (Wilding et al. 2000).

Most chemotherapeutics drugs are derived from plant compounds. For example, Taxol, the world-leading anti-cancer drug with an estimated revenue reaching USD \$80million globally (https://www.reportsweb.com/ reports/global-paclitaxel-market-growth-2019-2024) is derived from the Pacific yew's bark (Taxus brevifolia). Limonene is a plant monoterpene, synthesized specifically in the epidermal oil gland (Alonso et al. 1992) and is known as the main flavour compound in most Citrus species. Due to its pleasant fragrance, limonene has been utilized for commercial purposes in the fragrance industry. Over the last few decades, several studies have shown that limonene has a great potential as an anticancer agent against several types of cancer including colorectal cancer (Jia et al. 2013; Murthy et al. 2012). Tests in animals also have proven the effectiveness of limonene against some cancerous cells (Sun 2007).

Plants are known as the most extravagant source of isoprenoids; unfortunately, they do not produce these metabolites of interest in an appealing amount. The presence of many functional isoprenoids from their natural source are known to be low and the long-life cycles of plants also pose limitations in their production (Misawa 2011). In addition, high costs have hindered the application of chemical synthesis for the production of these compounds due to complexity of their structure, although it was proven successful for the production of certain isoprenoids such as Taxol and Carotenoids (Jackson et al. 2008; Kusama et al. 2000). An alternative strategy to overcome this challenge is possibly through engineering of microbial hosts for heterologous isoprenoids production. Microbes proves as an example of ideal hosts for isoprenoids production because of their fast growth rate, requirement for minimal resources, and are known for their natural ability to synthesize the universal precursors of isoprenoids which are isopentyl pyrophosphate (IPP) and dimethylallyl pyrophosphate (DMAPP) (Williams et al. 1998). These precursors are metabolized into geranyl pyrophosphate (GPP) which is the substrate for monoterpenes but can also be converted to farnesyl pyrophophate (FPP), which is the substrate for the production of sesquiterpenes and triterpenes.

L. lactis are non-pathogenic lactic acid bacteria used widely in the fermentation of food products. During the past 10 years, L. lactis was successfully developed into cell factories for the production of bioactive compounds such as enzymes, peptides and vaccine antigens (BaheyEl-Din et al. 2010; Pontes et al. 2011). This bacterium has also been classified as a GRAS (generally recognized as safe) organism due to the absence of endotoxins and inclusion bodies that are usually associated with the $E$. coli expression system (Cano-Garrido et al. 2014). In contrast with Lactobacilli spp., L. lactis is not a normal flora of the gastrointestinal tract, yet, it is still able to survive the gut microenvironment without colonizing it, making it suitable for transporting bioactive molecules such as vaccine antigens into the gut (Robinson et al. 1997).

Previously, we have cloned two sesquiterpene synthase from Vanda Mimi Palmer (orchid) and Persicaria minor (herb locally known as kesum), respectively, into $L$. lactis (Song et al. 2012a). Interestingly, only the synthase from $P$. minor successfully produced $\beta$-sesquiphellandrene in vivo while the germacrene synthase from Vanda Mimi Palmer did not, showing the discrepancy of isoprenoid production for different synthases in the same host. In the current study, a monoterpene synthase, limonene synthase, from Mentha spicate (mint) was cloned into L. lactis which was expected to produce limonene in vivo. This was performed with the aim of L. lactis to be potentially used to deliver anti-cancer compounds such as limonene via an oral delivery route, and especially against colorectal cancer, considering the target site of L. lactis. In addition, metabolic engineering efforts were conducted in an attempt to increase the production of limonene. To the best of our knowledge, this is the first study reported on the production of limonene by metabolic engineering of L. lactis as a cell factory and only the second monoterpene to be produced in L. lactis, the first being linalool (Hernandez et al. 2007).

\section{Materials AND METHOdS}

\section{BACTERIAL STRAINS AND GROWTH CONDITIONS}

The L. lactis NZ9000 host strain (Kuipers et al. 1998) used in this study is a nisin-negative derivative of $L$. lactis MG1363, where the nisR and nisK regulatory genes were incorporated into its chromosome. These genes allow the expression of the desired gene by nisin induction using the nisin promoter $\left(\mathrm{P}_{\text {nisA }}\right)$ in the pNZ8048 plasmid that was used as the expression vector in this study. The bacterium was cultured on M17 medium supplemented with $0.5 \%(\mathrm{w} / \mathrm{v})$ glucose (GM17) and grown at $30{ }^{\circ} \mathrm{C}$. When required, $7.5 \mu \mathrm{g} / \mathrm{mL}$ chloramphenicol was added to the medium. The M17 agar containing $0.5 \%(\mathrm{w} / \mathrm{v})$ glucose, 
$0.5 \mathrm{M}$ sucrose and $7.5 \mu \mathrm{g} / \mathrm{mL}$ chloramphenicol was used for screening of L. lactis transformants.

\section{GENE SYNTHESIS AND PCR AMPLIFICATION}

Nucleotide sequence of limonene synthase (LS) (Accession no: L13459) from Mentha spicata was optimized based on the codon frequency of L. lactis subsp. cremoris MG1363. The mature LS was synthesized with the removal of the 57 amino acid transit peptide located at the N-terminal. A his-tag sequence was incorporated at the N-terminal of the desired gene apart from the Pst I restriction site whereas the $\mathrm{C}$-terminal incorporated a $K p n I$ restriction site. The gene was synthesized by Biomatik Corporation, Cambridge, Canada. The mvaA (encoding HMGR) and $m v k$ (encoding mevalonate kinase) genes were amplified from $\mathrm{p} P M M$ plasmid that was previously constructed by Song et al. (2014). The mvaA gene was amplified using a forward primer 5'-AAAAAAATGAGAAAAAAATTTTATCAAATGTC-3'. This primer was incorporated with a RBS sequence (highlighted in grey) aside from the $K p n$ I site (underlined). The reverse primer 5'GGTGATGGTGATGTTTTCTCAAATTTTTTAGTA-3' was incorporated with a His-tag sequence (bold) aside from the $X b a \mathrm{I}$ site (underlined). Meanwhile the forward primer for $m v k$ gene AAAAAAATGACTATCAATAAAATGGGGACG-3' was designed with a RBS sequence (highlighted in grey) aside from $X b a$ I site (underlined). The $m v k$ reverse primer 5'-GATGGTGATGGTGATGAAAGGAGTAAATCCACG-3' was added with the His-tag sequence (bold) alongside the $\mathrm{SacI}$ site (underline). PCR was performed using KOD FX Neo Polymerase (Toyobo, Japan), following the manufacturer's protocol with an initial denaturation at 94 ${ }^{\circ} \mathrm{C}$ for $2 \mathrm{~min}$, followed by 29 cycles of $95^{\circ} \mathrm{C}$ for $10 \mathrm{~s}, 55^{\circ} \mathrm{C}$ for $30 \mathrm{~s}$, and extension at $68^{\circ} \mathrm{C}$ for $1 \mathrm{~min}$. The amplification was ended at $72{ }^{\circ} \mathrm{C}$ for $10 \mathrm{~min}$. The amplification of PCR products was analysed by agarose gel electrophoresis.

\section{CONSTRUCTION OF RECOMBINANT PLASMIDS}

The cloning of LS, mvaA and $m v k$ genes into pNZ8048 were performed separately. For construction of pNZ:LS plasmid, the LS gene and pNZ8048 were double digested with $P s t \mathrm{I}$ and $K p n \mathrm{I}$ restriction enzymes. For development of pNZ:LS :mvaA:mvk plasmid which is denoted as pNZ:LSMM henceforth, the amplified $m v a A$ gene was first cloned into the pNZ:LS via KpnI and $X b a \mathrm{I}$ restriction sites generating pNZ:LS : $m v a A$ followed by $m v k$ gene in between $X b a \mathrm{I}$ and $S a c$ I restriction sites. All digested PCR products were ligated into the corresponding double digested plasmid followed by transformation into competent L. lactis NZ9000 cells. Transformation was performed via the electroporation method using the Gene-Pulser (Bio-Rad, USA) that was set at $2.3 \mathrm{kV}, 25 \mu \mathrm{F}$ capacitance and $200 \Omega$ resistance, resulting in time constant of $4.5-5.0 \mathrm{~ms}^{-1}$. A total of 500 $\mu \mathrm{L}$ of the cells were spread on SGM17 agar supplemented with $7.5 \mu \mathrm{g} / \mathrm{mL}$ of chloramphenicol and the plates were placed in $30{ }^{\circ} \mathrm{C}$ incubator for $48 \mathrm{~h}$ to allow the growth of transformants. For initial screening, colony PCR was performed using primers flanking the MCS region of pNZ8048 plasmid. The primers sequences were 5'-TATTGTCGATAACGCGAGCA-3' for forward primer and 5'-CGTTTCAAGCCTTGGTTTTC-3' for reverse primer. Subsequently, the colonies were extracted and the plasmid was further verified by double digestion and DNA sequencing.

\section{PROTEIN EXPRESSION}

Overnight grown cultures of L. lactis containing recombinant plasmids were inoculated into fresh GM17 medium containing $7.5 \mu \mathrm{g} / \mathrm{mL}$ of chloramphenicol and incubated at $30^{\circ} \mathrm{C}$ until an $\mathrm{OD}_{600 \mathrm{~nm}}$ of $0.4-0.5$ was reached. The culture was separated into three groups i) uninduced samples and ii) nisin $(10 \mathrm{ng} / \mathrm{mL})$ induced samples and incubated for $2-12 \mathrm{~h}$ at $30{ }^{\circ} \mathrm{C}$ iii) samples induced at different nisin concentration 10, 20, 40, and $60 \mathrm{ng} / \mathrm{mL}$ and incubated for $2 \mathrm{~h}$ at $30^{\circ} \mathrm{C}$. After induction, the cells were harvested by centrifugation at $1500 \times \mathrm{g}$ for $10 \mathrm{~min}$ at $4{ }^{\circ} \mathrm{C}$, followed by washing and resuspension in 1:10 phosphate buffer saline (PBS). The cells were sonicated using the Omni Ruptor 4000 (Omni International, GA, USA) set to $40 \%$ power and pulsed for 6-8 min per sample, then chilled on ice for $2 \mathrm{~min}$. The suspension was centrifuged at $10,000 \times \mathrm{g}$, for $10 \mathrm{~min}$, at $4{ }^{\circ} \mathrm{C}$ with the resulting supernatant further subjected to protein quantification using Quick Start Bradford protein assay (Biorad, CA, USA).

\section{SDS-PAGE ANALYSIS}

SDS-PAGE analysis was performed based on Laemmli (1970) protocol. The mixture of protein containing 3 volume of samples and 1 volume of $4 \times$ sample buffer (0.5 M Tris- $\mathrm{HCl} \mathrm{pH} 6.8,10 \%$ (w/v) SDS, 80\% (v/v) glycerol, $0.05 \%(\mathrm{w} / \mathrm{v})$ bromophenol blue, $5 \%(\mathrm{v} / \mathrm{v})$ beta-mercaptoethanol) was prepared. The mixture was boiled for $8 \mathrm{~min}$ to denature the proteins before being run on a $12 \%$ denaturing polyacrylamide gel. The gel was ran at $95.0 \mathrm{~V}$ for $1.5 \mathrm{~h}$ or until the loading 
dye reached at the end of the gel. After electrophoresis was completed, the stacking gel was removed from the resolving gel and soaked in gel-washing solution $(50 \%$ $(\mathrm{v} / \mathrm{v})$ methanol, $10 \%(\mathrm{v} / \mathrm{v})$ glacial acetic acid) for $10 \mathrm{~min}$ at room temperature with slow agitation. Then, the gelwashing solution was discarded and the Coomasie Blue Staining Solution $(0.125 \mathrm{~g}(\mathrm{w} / \mathrm{v})$ Coomassie blue R-250, $40 \%(\mathrm{v} / \mathrm{v})$ methanol, 7\% (v/v) acetic acid) was added into the gel. The gel was stained for 15-30 min at room temperature with slow agitation as well. After that, the staining solution was removed and the gel was destained again with Destaining solution I (40\% (v/v) methanol, $7 \%(\mathrm{v} / \mathrm{v})$ glacial acetic acid) for $30 \mathrm{~min}$ twice. Finally, the Destaining solution I was discarded and replaced with Destaining Solution II (5\% (v/v) methanol, 7\% (v/v) glacial acetic acid) for overnight or until the bands were clearly visible.

\section{WESTERN BLOT ANALYSIS}

The analysis of Western blot was carried out according to the protocol of Towbin et al. (1979) with minor alterations. After electrophoresis, the resolved polypeptides were transferred onto polyvinyllidene difluoride (PVDF) membrane using a Novex ${ }^{\circledR}$ Semi-Dry Blotter (Invitrogen, USA) at $65 \mathrm{~mA}$ for $1 \mathrm{~h} 15 \mathrm{~min}$. The proteins were detected using the primary antibody of mouse IgG His-Tag Monoclonal Antibody (Novagen, NJ, USA) at 1:1000 dilution while secondary antibody used was horse radish peroxidase (HRP) conjugated goat anti-mouse $\operatorname{IgG}$ (Calbiochem, CA, USA) using the same dilution factor. The DAB substrate solution was poured on the membrane to enable chromogenic detection of secondary antibody HRP conjugate.

\section{GC-MS ANALYSIS}

The detection of limonene production was performed using the Agilent 7890A GC-MS System (Agilent, CA, USA) and the GC column used for separation was Agilent VF 5-MS $(30 \mathrm{~m} \times 0.25 \mathrm{~mm})$. Overnight grown cultures of L. lactis harbouring pNZ:LS or was inoculated into $100 \mathrm{~mL}$ serum bottle containing fresh GM17 media containing $7.5 \mu \mathrm{g} / \mathrm{mL}$ of chloramphenicol. The cultures were incubated at $30^{\circ} \mathrm{C}$ until an $\mathrm{OD}_{600 \mathrm{~mm}}$ of $0.4-0.5$ was reached. Then, the cultures were induced with $10 \mathrm{ng} / \mathrm{mL}$ nisin and sampled for limonene production after 2, 24, and $48 \mathrm{~h}$ post-induction (hpi) at $30^{\circ} \mathrm{C}$. The cultures were extracted by sampling the headspace in the serum bottles using solid-phase microextraction (SPME) technique that involved the use of a polydimethylsiloxane (PDMS) coated fiber at $60^{\circ} \mathrm{C}$ for $15 \mathrm{~min}$. The PDMS fiber was then injected into the injection port of the GC-MS machine with the settings of initial temperature at $40^{\circ} \mathrm{C}(1 \mathrm{~min})$ to 250 ${ }^{\circ} \mathrm{C}(3 \mathrm{~min})$ with $35^{\circ} \mathrm{C}$ ramping temperature increased at $35^{\circ} \mathrm{C}$ per min. The column flow was maintained at $1 \mathrm{~mL} / \mathrm{min}$. The injection port was set at $250{ }^{\circ} \mathrm{C}$ with split-less mode injector programme. The transfer line was set up at $220^{\circ} \mathrm{C}$ while the MS source temperature was held constant at $200^{\circ} \mathrm{C}$. The ionization voltage (IE) was operated at $70 \mathrm{eV}$ with MS was set in selected ion monitoring (SIM) mode using ion of $\mathrm{m} / \mathrm{z} 93$ as it was specific for ion fragment of monoterpene hydrocarbon. The limonene production was identified by comparison of the retention time and mass spectra to the National Institute of Standards and Technology (NIST) library 2011. The quantification of the limonene production was accomplished by comparison with a standard curve using commercial limonene (Sigma-Aldrich, MO, USA).

\section{RESULTS AND DISCUSSION}

\section{PLASMID CONSTRUCTION}

The LS was synthesized with the removal of the transit peptide at the cleavage site located at the N-terminal calculated from the first 57 amino acid residues. Hence, the truncated version of the enzyme is closely similar to the mature form of the LS as reported by Williams et al. (1998). The PCR-amplified fragments of LS were shown to be at the correct estimated size of $\sim 1.7 \mathrm{~kb}$ (exact size $1662 \mathrm{bp}$ ) including the RE sites and His-tag sequence. The clones of LS into pNZ8048 was referred as pNZ:LS recombinant plasmid. The insertion of the 1,251 bp mvaA $(\sim 1.2 \mathrm{~kb})$ and $951 \mathrm{bp} m v k$ ( $\sim 900 \mathrm{bp})$ genes downstream LS gene resulted with the pNZ:LSMM recombinant (Figure 1 ). DNA sequencing confirmed $100 \%$ identity with the expected sequence (S1).

\section{EXPRESSION OF RECOMBINANT PROTEINS}

For the expression of recombinant protein, the optimization of induction time and nisin concentration were conducted in order to obtain an optimum induction condition. First, pNZ:LS was optimized at different induction time at $2,4,6,8$, and $12 \mathrm{~h}$ with $10 \mathrm{ng} / \mathrm{mL}$ of nisin followed by nisin concentration optimization at 10 , 20, 40, and $60 \mathrm{ng} / \mathrm{mL}$. From the SDS-PAGE analysis of the total crude protein for L. lactis NZ9000 harbouring pNZ:LS, no distinct band was visible at $55 \mathrm{kDa}$ when 
comparing between the induced and non-induced samples as shown in Figure 2(a). This might be due to similarly sized endogenous proteins that masked the expected band of the recombinant proteins. Therefore, Western blot analysis was carried out using mouse IgG His-Tag monoclonal antibody which showed the presence of a clear distinct band of LS at $55 \mathrm{kDa}$ (Figure 2(b)), which is similar to the size of the native LS enzyme (Colby et al. 1993). It was shown that LS was expressed

(a)

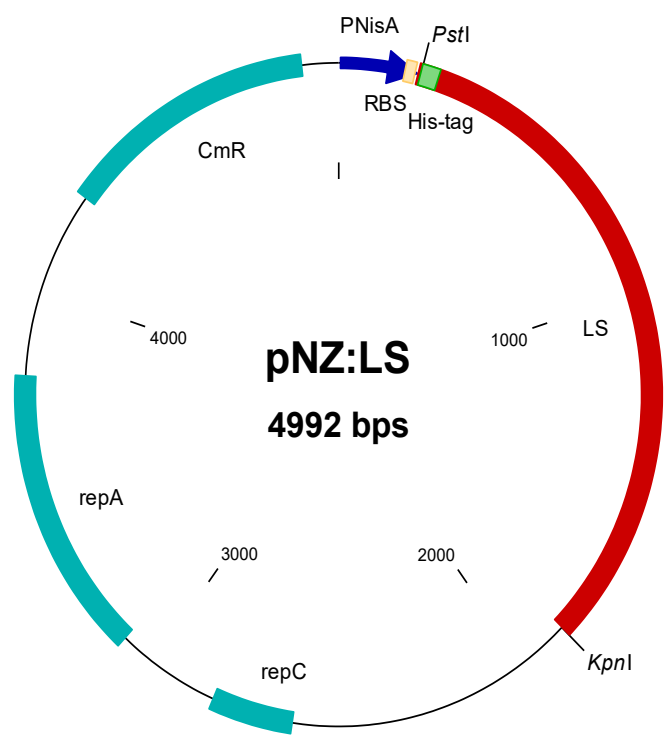

as early as $2 \mathrm{~h}$ post-induction which did not increase when the time was prolonged. In the nisin concentration optimization Western Blot, all bands were also present at different concentrations of nisin at similar intensities (Figure 3). Therefore, $2 \mathrm{~h}$ post-induction time with 10 $\mathrm{ng} / \mathrm{mL}$ of nisin concentration was chosen as the optimum induction condition due to the least time and nisin required to express the desired proteins. This induction condition was also used for the recombinant clones (b)

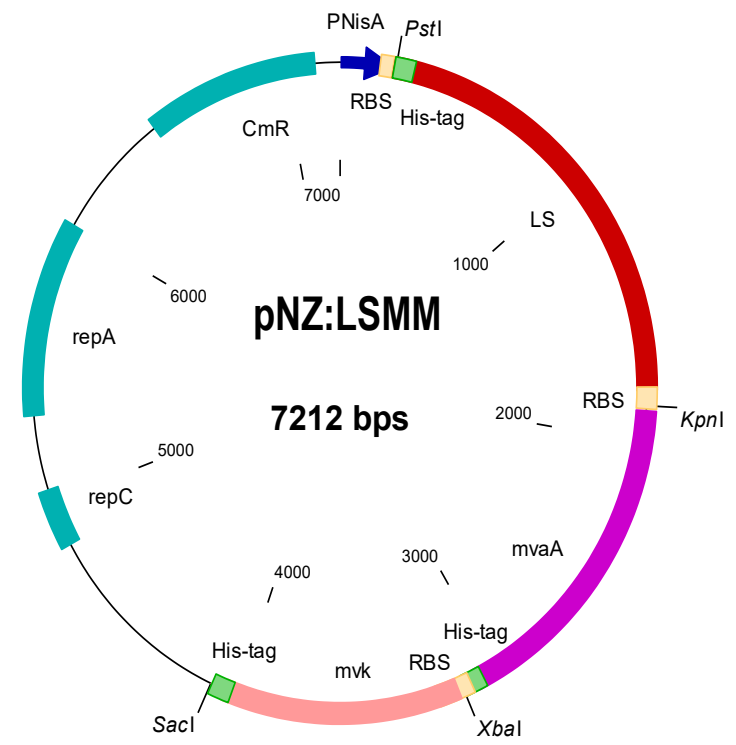

FIGURE 1. Schematic diagram of the constructed recombinant L. lactis carrying the pNZ:LS and pNZ:LSMM plasmids

harbouring pNZ:LSMM which showed three dominant bands detected which is representive for LS protein at $\sim 55$ $\mathrm{kDa}$ (red arrow), mvaA protein at $\sim 43 \mathrm{kDa}$ (blue arrow) and MVK protein at $\sim 34 \mathrm{kDa}$ (green arrow) (Figure 4). These three genes had their own ribosomal binding sites prior to the start codon; therefore, they were expressed as separate proteins. However, leaky expression was observed for mvaA protein as it produced a band even in the non-induced sample (Figure 4, Lane 2). It should be noted that the band for the HMGR protein is more intense compared to LS and MVK proteins. This could possibly be the reason HMGR could be observed even in the non-induce sample, due to the abundance of expression of this protein. It should also be noted that both HMGR and MVK proteins are endogenous to L. lactis while LS is a plant gene which expression is understandably low. However, MVK expression was observed to be notably low despite being an endogenous protein. This could be due to the distance of the $m v k$ gene from the promoter (third gene). Kim et al. (2004) previously reported that when two genes were expressed from a single promoter (bicistronic vector), it often resulted in the second gene being expressed at a lower level compared to the first gene. Similarly, in our previous study using this bicistronic vector strategy where $\beta$-sesquiphellandrene synthase was cloned as the first gene, $m v k$ as the second gene and mvaA as the third gene, it was observed that the $m v k$ band was more intense than the mvaA band (Song et al. 2014). Kim et al. (2004) suggested using a dualpromoter vector to overcome this problem. 
a)

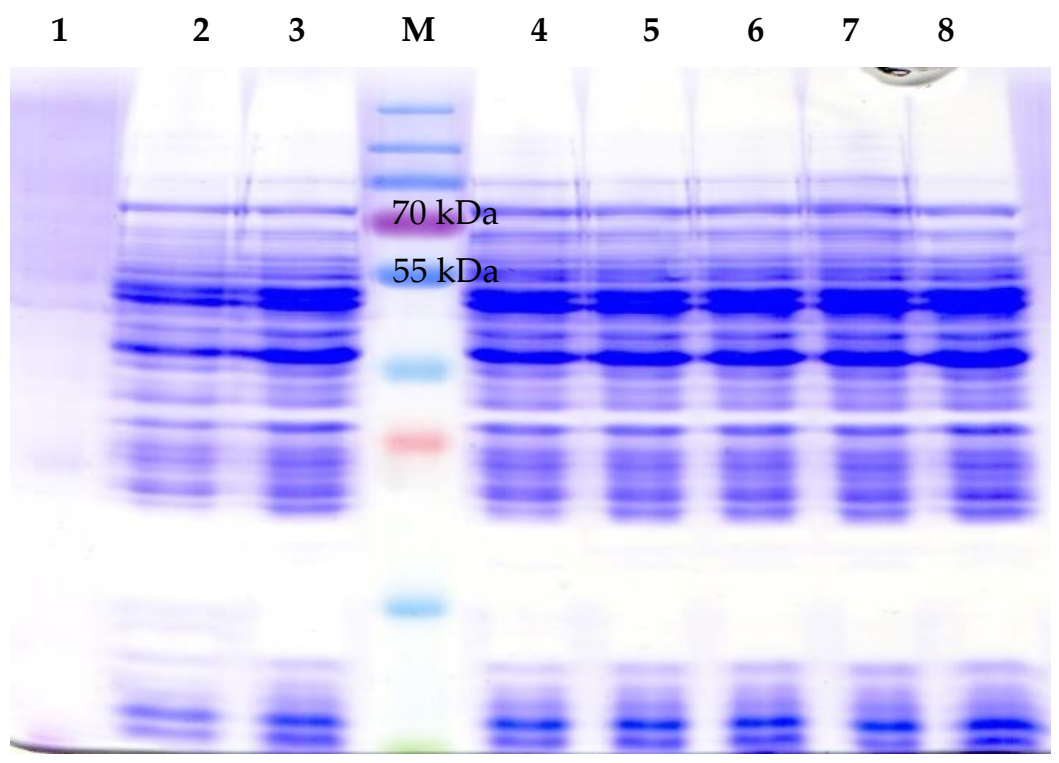

b)

$\begin{array}{llll}M & 4 & 5 & 6\end{array}$

$7 \quad 8$

\section{$70 \mathrm{kDa}$}

$55 \mathrm{kDa}-\frac{\mathrm{LS}}{\mathrm{T}}$

FIGURE 2. Optimization of the expression time for recombinant L. lactis harbouring pNZ:LS plasmids. a) SDS-PAGE and b) Western blot analysis of the crude extract of pNZ:LS recombinant protein is shown. Lane M: PageRuler Plus Prestained Protein Ladder (Fermentas, USA). Lane 1: WB Positive control. Lane 2: L. lactis NZ9000. Lane 3: Noninduced sample of pNZ:LS. Lanes 4-8: pNZ:LS induced with $10 \mathrm{ng} / \mathrm{mL}$ nisin for $2,4,6,8$ and $12 \mathrm{~h}$, respectively 
FIGURE 3. Optimization of the nisin concentration for recombinant L. lactis harbouring pNZ:LS plasmids as shown by Western blot analysis. Lane M: PageRuler Plus Prestained Protein Ladder (Fermentas, USA). Lane 1: Positive control, LS protein. Lane 2: L. lactis NZ9000. Lane 3: Non-induced sample of pNZ:LS. Lane 4-7. pNZ:LS plasmid induced for 2 $\mathrm{h}$ at $10,20,40$ and $60 \mathrm{ng} / \mathrm{mL}$ nisin, respectively

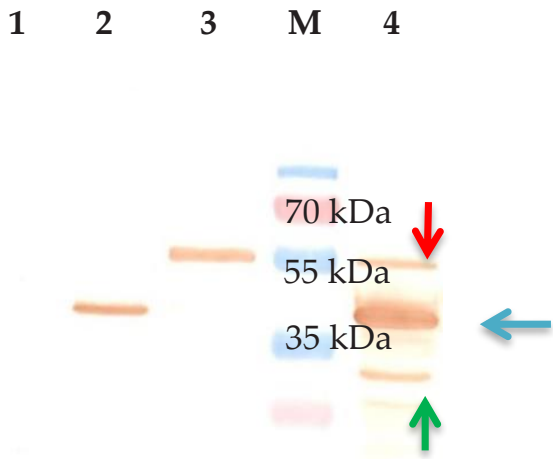

FIGURE 4. Western blot analysis of the crude extract pNZ:LSMM recombinant protein. Lane M: PageRuler Plus Prestained Protein Ladder (Fermentas, USA). Lane 1: L. lactis NZ9000. Lane 2: Non-induced sample of pNZ:LSMM. Lane 3: Positive control, LS protein. Lane 4: $\mathrm{pNZ}$ :LSMM induced for $2 \mathrm{~h}$ at $10 \mathrm{ng} / \mathrm{mL}$. All three expected proteins were successfully expressed. Red arrow: LS, blue arrow: HMGR, green arrow: MVK 


\section{DETERMINATION OF LIMONENE CONTENT IN RECOMBINANT L. lactis CULTURE}

The limonene production was determined by GC-MS analysis. The $\mathrm{m} / \mathrm{z} 93$ ion fragment was selected for analysis instead of total ion chromatogram as it is the base peak for most monoterpene hydrocarbons (Thao et al. 2007). The recombinant $L$. lactis harbouring pNZ:LS was capable of producing limonene by using the host's GPP precursors. However, our result showed that the yield of limonene produced was comparatively low ( 4.0-8.0 ppm) even after optimization up to $48 \mathrm{~h}$ post-induction (Figure 5). The low level of limonene production could probably be attributed by the poor flux of monoterpene precursors such as GPP due to rate-limiting enzymes in the pathway (Jongedijk et al. 2016).

Metabolic engineering effort was performed by cloning and expressing the endogenous L. lactis HMGR
(mvaA) and $m v k$ genes alongside the LS gene using the high-copy number plasmid, pNZ8048, in order to further enhance the synthesis of limonene. The resultant engineered strain harbouring pNZ:LSMM had a 1.6-fold increase in limonene production, reaching a titre of $15.1 \mathrm{ppm}$ at $24 \mathrm{hpi}$ (Figure 5). This result was similar with our previous studies where co-expression of mvaA with $m v k$ genes improved production of the plant sesquiterpene $\beta$-sesquiphellandrene from a leafy fragrant plant, Persicaria minor, which was increased by two folds (Song et al. 2014). The identification of limonene was confirmed by comparing the retention time and mass spectra to the National Institute of Standards and Technology (NIST) library 2011. An example of the mass spectra for pNZ:LSMM is shown in Figure 6. The production was quantified with the standard curve using different concentrations (1-1000 ppm) of commercial limonene.

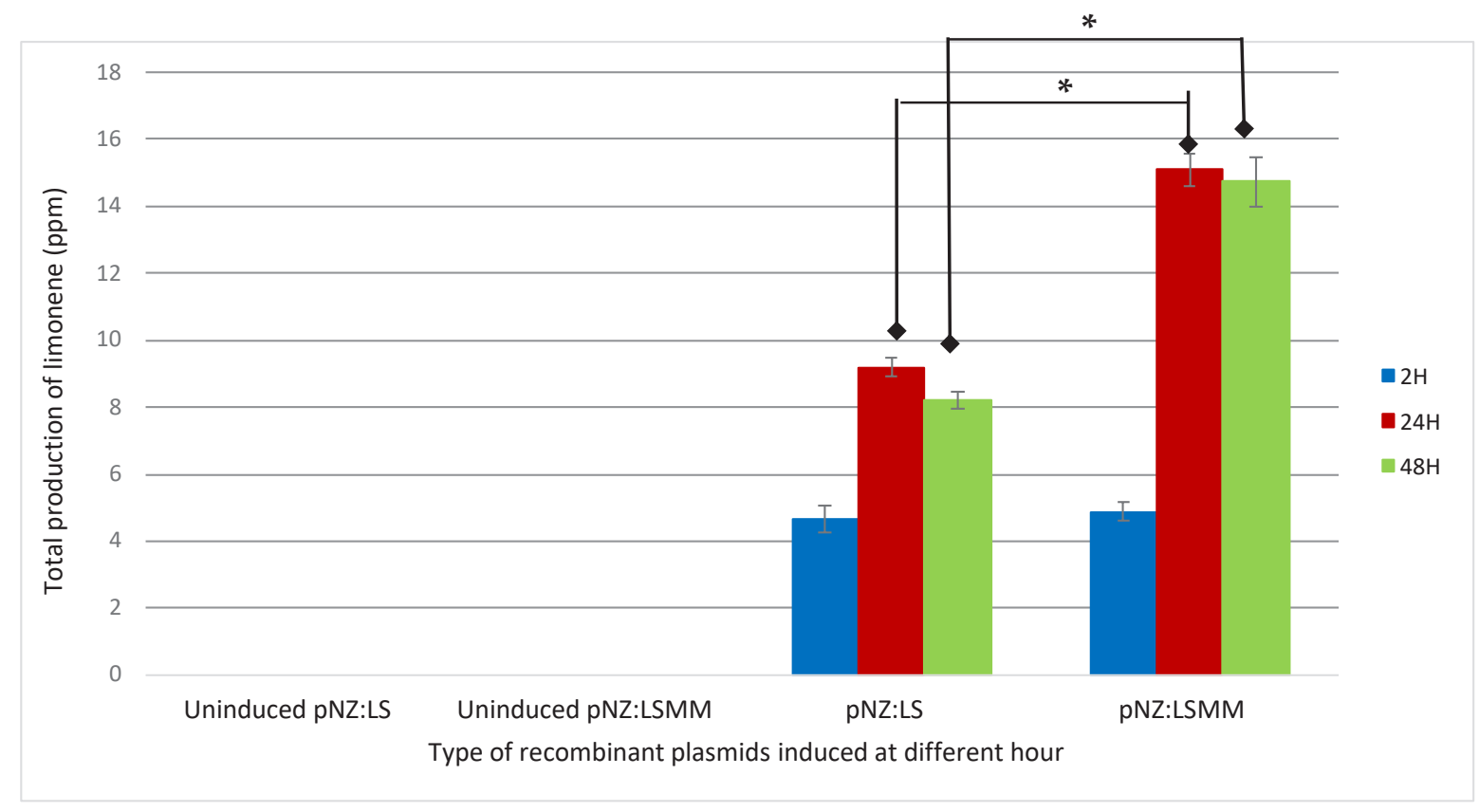

FIGURE 5. Optimization of limonene production by L. lactis NZ9000 harbouring pNZ:LS and pNZ:LSMM. Productions were measured at 2, 24 and $48 \mathrm{~h}$ of nisin induction $(10 \mathrm{ng} / \mathrm{mL})$. Results shown the average five of biological replicates with error bars representing \pm standard error of the mean (SEM) and * indicates significance $\mathrm{p}<0.05$

Although the metabolic engineering strategy of combining the expression of a synthetic limonene synthase with HMGR and mevalonate kinase had improved the production of limonene in this study, the amount yielded did not attain the $\mathrm{LD}_{50}$ value to inhibit the proliferation of cancer cells which was reported to be $50 \mathrm{ppm}$ for SW480 and 100 ppm for HT29 colorectal cancer cell lines (Murthy et al. 2012). The future aim of this recombinant L. lactis strain is to test its ability to deliver anti-cancer compounds such as limonene to 
colorectal cancer sites via oral delivery. Therefore, efforts are now focused at identifying the pathway bottlenecks to maximize the flux and optimize expression of the prokaryotic mevalonate pathway before the system can be used in in-vivo studies.

a) pNZ:LSMM

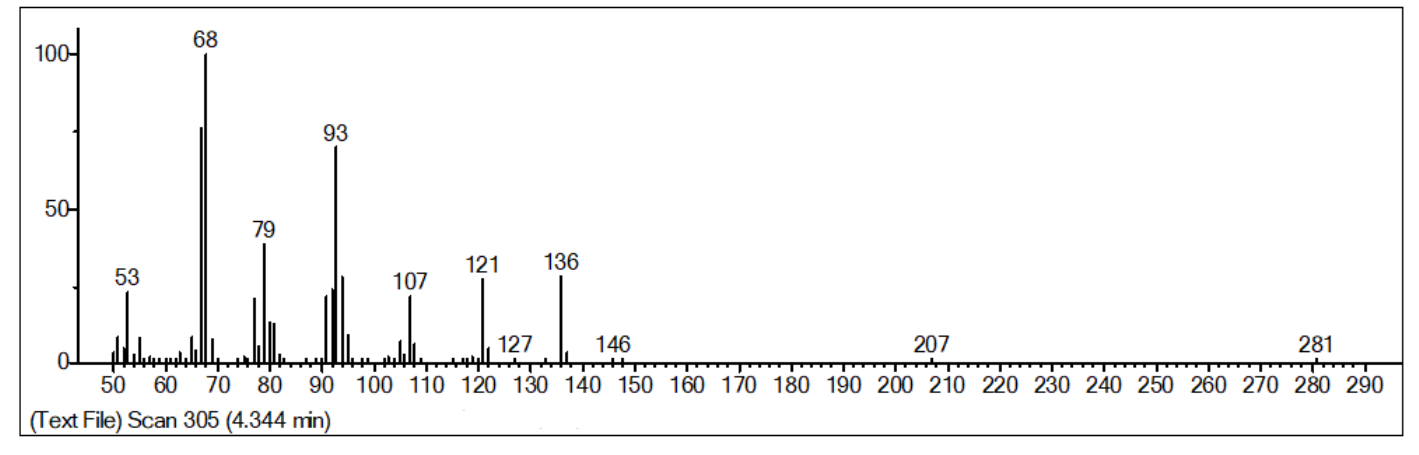

b) NIST Library

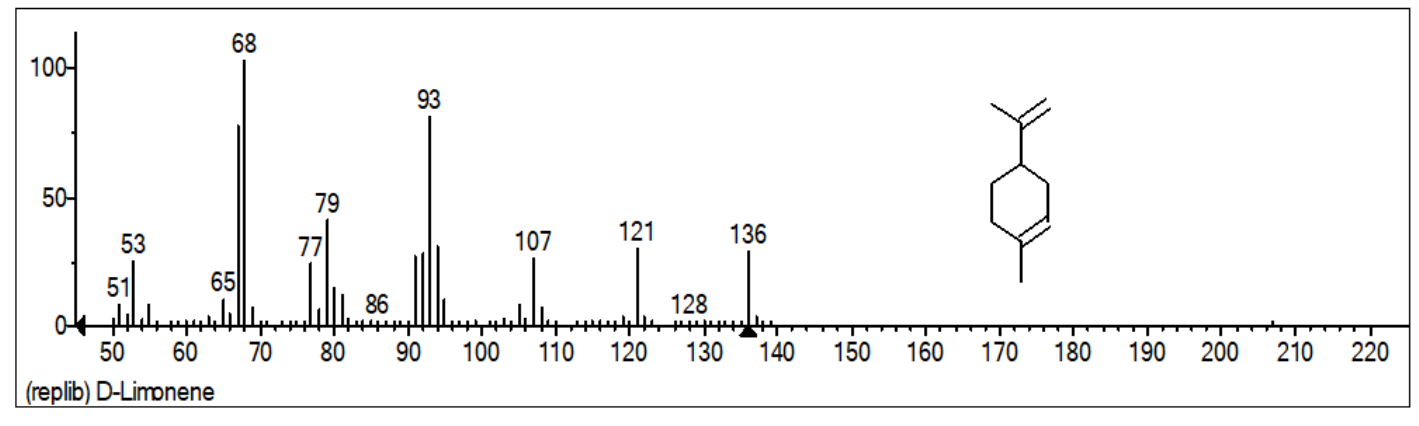

FIGURE 6. Mass spectra of limonene produced by recombinants L. lactis carrying a) pNZ:LSMM plasmid in comparison with corresponding mass spectra of limonene from b) NIST (2011) library

\section{CONCLUSION}

The present study demonstrated the development of L. lactis as a microbial cell factory for the production of plant monoterpene specifically limonene using a heterologous mevalonate pathway. The metabolic engineering strategy significantly increased the limonene production to two-fold higher with a yield of $15.1 \mathrm{ppm}$ at $24 \mathrm{hpi}$. The synergistic effect of $\mathrm{mvaA}$ and $m v k$ genes was proven to enhance the limonene production. Optimization work and further studies are crucial to improve limonene production before the system can be applied as a possible chemotherapy alternative for colorectal cancer in the future.

\section{ACKNOWLEDGEMENTS}

This research is supported by research grant GPIPS/2015/9451000 under Universiti Putra Malaysia (UPM), Serdang, Selangor, Malaysia and Science Fund 02-02-22-SF0011 under Ministry of Science, Technology and Innovation (MOSTI), Malaysia. The authors thank Miss Nur Suhanawati Ashaari from the Malaysian Genome Institute (MGI) for her guidance and advice 
with the GC-MS analysis. RAR, JOA, AAS, and LLI were involved in conception of the research design. AAS and SO supervised the experiment and revised the manuscript. RAR and JOA contributed reagents/ materials/analysis tools. NAS performed the experiments and wrote the manuscript. All authors read and approved the final manuscript. The authors declare that they have no competing interest.

\section{REFERENCES}

Alonso, W.R., Rajaonarivony, J.I.M., Gershenzon, J. \& Croteau, R. 1992. Purification of 4S-limonene synthase, a monoterpene cyclase from the glandular trichomes of peppermint (Mentha x piperita) and spearmint (M. spicata). Journal of Biological Chemistry 267(11): 7582-7587.

Alonso-Gutierrez, J., Chan, R., Batth, T.S., Adam, P.D., Keasling, J.D., Petzold, C.J. \& Lee, T.S. 2013. Metabolic engineering of Escherichia coli for limonene and perillyl alcohol production. Metabolic Engineering 19: 33-41.

Bahey-El-Din, M., Gahan, C.G.M. \& Griffin, B.T. 2010. Lactococcus lactis as a cell factory for delivery of therapeutic proteins. Current Gene Therapy 10(1): 34-45.

Cano-Garrido, O., Rueda, F.L., Sànchez-García, L., Ruiz-Ávila, L., Bosser, R., Villaverde, A. \& García-Fruitós, E. 2014. Expanding the recombinant protein quality in Lactococcus lactis. Microbial Cell Factory 13: 167.

Colby, S.M., Alonso, W.R., Katahira, E.J., McGarvey, D.J. \& Croteau, R. 1993. 4S-limonene synthase from the oil glands of spearmint (Mentha spicata). cDNA isolation, characterization, and bacterial expression of the catalytically active monoterpene cyclase. Journal of Biological Chemistry 268(31): 23016-23024.

Crocoll, C., Asbach, J., Novak, J., Gershenzon, J. \& Degenhardt, J. 2010. Terpene synthases of oregano (Origanum vulgare L.) and their roles in the pathway and regulation of terpene biosynthesis. Plant Molecular Biology 73(6): 587-603.

Global Paclitaxel Market Growth 2019-2024. https://www. reportsweb.com/reports/global-paclitaxel-marketgrowth-2019-2024. Accessed on 9 march 2020.

Hernandez, I., Molenaar, D., Beekwilder, J., Bouwmeester, H. \& van Hylckama Vlieg, J.E. 2007. Expression of plant flavor genes in Lactococcus lactis. Applied and Environmental Microbiology 73(5): 1544-1552.

Jackson, H., Braun, C.L. \& Ernst, H. 2008. The chemistry of novel xanthophyll carotenoids. The American Journal of Cardiology 101(10A): 50D-57D.

Jia, S.S., Xi, G.P., Zhang, M., Chen, Y.B., Lei, B., Dong, X.S. \& Yang, Y.M. 2013. Induction of apoptosis by D-limonene is mediated by inactivation of Akt in LS174T human colon cancer cells. Oncology Reports 29(1): 349-354.

Jongedijk, E., Cankar, K., Buchhaupt, M., Schrade, J., Bouwmeester, H. \& Beekwilder, J. 2016. Biotechnological production of limonene in microorganisms. Applied Microbiology and Biotechnology 100: 2927-2938.
Kim, K.J., Kim, H.E., Lee, K.H., Han, W., Yi, M.J., Jeong, J. \& Oh, B.H. 2004. Two-promoter vector is highly efficient for overproduction of protein complexes. Protein Science 13(6): 1698-1703.

Kuipers, O.P., Ruyter, P.G.G.A.D., Kleerebezem, M. \& Vos, W.M.D. 1998. Quorum sensing-controlled gene expression in lactic acid bacteria. Journal of Biotechnology 64(1): 15-21.

Kusama, H., Hara, R., Kawahara, S., Nishimori, T., Kashima, H., Nakamura, N., Morihira, K. \& Kuwajima, I. 2000. Enantioselective total synthesis of (-)-taxol. Journal of the American Chemical Society 122(16): 3811-3820.

Laemmli, U.K. 1970. Cleavage of structural proteins during the assembly of the head of bacteriophage T4. Nature 227(5259): 680-685.

Misawa, N. 2011. Pathway engineering for functional isoprenoids. Current Opinion in Biotechnology 22(5): 627633.

Murthy, K.N.C., Jayaprakasha, G.K. \& Patil, B.S. 2012. D-limonene rich volatile oil from blood oranges inhibits angiogenesis, metastasis and cell death in human colon cancer cells. Life Sciences 91(11-12): 429-439.

Pitera, D.J., Paddon, C.J., Newman, J.D. \& Keasling, J.D. 2007. Balancing a heterologous mevalonate pathway for improved isoprenoid production in Escherichia coli. Metabolic Engineering 9(2): 193-207.

Pontes, D.S., de Azevedo, M.S., Chatel, J.M., Langella, P., Azevedo, V. \& Miyoshi, A. 2011. Lactococcus lactis as a live vector: Heterologous protein production and DNA delivery systems. Protein Expression and Purification 79(2): 165-175.

Reiling, K.K., Yoshikuni, Y., Martin, V.J., Newman, J., Bohlmann, J. \& Keasling, J.D. 2004. Mono and diterpene production in Escherichia coli. Biotechnology and Bioengineering 87(2): 200-212.

Robinson, K., Chamberlain, L.M., Schofield, K.M., Wells, J.M. \& Le Page, R.W. 1997. Oral vaccination of mice against tetanus with recombinant Lactococcus lactis. Nature Biotechnology 15(7): 653-657.

Rodríguez-Concepción, M. \& Boronat, A. 2002. Elucidation of the methylerythritol phosphate pathway for isoprenoid biosynthesis in bacteria and plastids. A metabolic milestone achieved through genomics. Plant Physiology 130(3): 10791089.

Song, A.A.L., Abdullah, J.O., Abdullah, M.P., Shafee, N., Othman, R., Noor, N.M. \& Raha, A.R. 2014. Engineering the lactococcal mevalonate pathway for increased sesquiterpene production. Microbiology Letters 355(2): 177-184.

Song, A.A.L., Abdullah, J.O., Abdullah, M.P., Shafee, N. \& Raha, A.R. 2012a. Functional expression of an orchid fragrance gene in Lactococcus lactis. International Journal of Molecular Sciences 13(2): 1582-1597.

Song, A.A.L., Abdullah, J.O., Abdullah, M.P., Shafee, N., Othman, R., Tan, E.F., Noor, N.M. \& Raha, A.R. 2012 b. Overexpressing 3-hydroxy-3-methylglutaryl coenzyme A reductase (HMGR) in the lactococcal mevalonate 
pathway for heterologous plant sesquiterpene production. PLoS ONE 7(12): e52444.

Sun, J. 2007. D-limonene: Safety and clinical applications. Alternative Medicine Review 12(3): 259-264.

Thao, N.T., Kashiwagi, T. \& Sawamura, M. 2007. Characterization by GC-MS of Vietnamese citrus species and hybrids based on the isotope ratio of monoterpene hydrocarbons. Bioscience, Biotechnology, and Biochemistry 71(9): 2155-2161.

Tsuruta, H., Paddon, C.J., Eng, D., Lenihan, J.R., Horning, T., Anthony, L.C., Regentin, R., Keasling, J.D., Renninger, N.S. \& Newman, J.D. 2009. High-level production of amorpha4,11-diene, a precursor of the antimalarial agent artemisinin, in Escherichia coli. PLoS ONE 4(2): 4489.

Wang, G.Y. \& Keasling, J.D. 2002. Amplification of HMG-CoA reductase production enhances carotenoid accumulation in Neurospora crassa. Metabolic Engineering 4(3): 193-201.

Wilding, E.I., Brown, J.R., Bryant, A.P., Chalker, A.F., Holmes, D.J., Ingraham, K.A., Iordanescu, S., So, C.Y., Rosenberg, M. \& Gwynn, M.N. 2000. Identification, evolution, and essentiality of the mevalonate pathway for isopentenyl diphosphate biosynthesis in Gram-positive cocci. Journal of Bacteriology 182(15): 4319-4327.

Williams, D.C., McGarvey, D.J., Katahira, E.J. \& Croteau, R. 1998. Truncation of limonene synthase preprotein provides a fully active 'pseudomature' form of this monoterpene cyclase and reveals the function of the amino-terminal arginine pair. Biochemistry 37(35): 12213-12220.

Yang, J., Nie, Q., Ren, M., Feng, H., Jiang, X., Zheng, Y., Liu, M., Zhang, H. \& Xian, M. 2013. Metabolic engineering of Escherichia coli for the biosynthesis of alpha-pinene. Biotechnology for Biofuels 6(1): 60.
Nurul 'Aishah Shaili, Sarah Othman, Janna Ong-Abdullah \& Raha Abdul Rahim

Department of Cell and Molecular Biology

Faculty of Biotechnology and Biomolecular Sciences

Universiti Putra Malaysia

43400 Serdang, Selangor Darul Ehsan

Malaysia

Adelene Ai-Lian Song*

Department of Microbiology

Faculty of Biotechnology and Biomolecular Sciences

Universiti Putra Malaysia

43400 Serdang, Selangor Darul Ehsan

Malaysia

Adelene Ai-Lian Song \& Raha Abdul Rahim

Institute of Bioscience

Universiti Putra Malaysia

43400 Serdang, Selangor Darul Ehsan

Malaysia

Lionel Lian Aun In

Department of Biotechnology

Faculty of Applied Sciences

UCSI University, KL Campus

56000 Kuala Lumpur, Federal Territory

Malaysia

*Corresponding author; email: adelene@upm.edu.my

Received: 25 December 2020

Accepted: 25 May 2021 